\title{
Protecting the University as a Physical Place in the Age of Postdigitization
}

\author{
Ryan M. Allen ${ }^{1}$ D . Peter McLaren ${ }^{1,2}$
}

Accepted: 15 November 2021 / Published online: 22 December 2021

(c) The Author(s), under exclusive licence to Springer Nature Switzerland AG 2021

\begin{abstract}
Covid-19 forced higher education sectors across the world to digitize the entire university experience online. There are now calls for universities to continue chasing continued and further digitization, often from for-profit businesses and those in Silicon Valley who have been promising to disrupt the sector for decades. We argue that the pandemic has illustrated how crucial universities are to their local communities, and efforts should be made to emphasize their physical place and space. The destruction of American cities in favor of auto-centric suburbs provides a parallel for the possible future of higher education. The Cult of Efficiency mindset and accountability models that dominated neoliberal discourse offered the impetus for highway construction through city centers, often razing Black neighborhoods and ruining communities and culture along the way. The calls for the full digitization of universities echo this same possible destruction for the sector. This is not a Luddite warning to reject all digitization, instead, it is a rejection of the hyper-capitalization of higher education and the disruption promised by for-profit businesses, along with a reminder that the sector should be a local public good.
\end{abstract}

Keywords Suburbanization · Digitization · Place and space · Urbanism · Future of higher education $\cdot$ Localism $\cdot$ Postdigital

\section{University Place and Space in the Age of Covid-19}

In 1997, Peter Drucker, famed management consultant and educator, proclaimed, '[u]niversities won't survive. The future is outside the traditional campus, outside the traditional classroom. Distance learning is coming on fast.' (in Doyle 2009) Drucker's apocryphal alarm did not come true until it was finally breathed to life by

Ryan M. Allen

ryallen@chapman.edu

1 Chapman University, Orange, USA

2 Northeast Normal University, Changchun, China 
a once-in-a-century global pandemic. It was technological innovation that allowed schools and universities to remain open during the Covid-19 pandemic in numerous ways, primarily by offering lectures and classes synchronously or asynchronously. While educators and students are lauded for adaptability in a crisis (Jandrić et al. 2020, 2021a; Bista et al. 2021), these new measures should be recognized as Band-Aids and not total replacements for traditional educational settings. Hodges et al. (2020) dubbed these adopted practices during the pandemic as emergency remote teaching (ERT), arguing that they should stay in an educators' toolkit given the uncertainties of future crises or events.

Yet, EdTech start-ups, Silicon Valley, and other commercial enterprises are leading the drumbeat for the permanent digitization of curriculum that does not require learners to inhabit any particular physical location. Google and Facebook have been attempting to 'disrupt' higher education with online micro-credentials, efforts that long predate the pandemic (Ralston 2021). Times Higher Education even suggested that the 'bricks-and-mortar estates' of universities are merely expensive debt burdens and should be cast aside for digitalization like Artificial Intelligence (AI) student services (Baines 2021). In our estimation, these arguments are absolutely the wrong takeaway from the pandemic and are a surefire means to lead institutions into pedagogical oblivion in the coming decades.

Universities should realize that their physical spaces are more important than ever before precisely because they cannot be replicated digitally. We are not espousing an argument for Luddism, the 'primitivist refusal of innovation' already decried by Marx (Jandrić and McLaren 2020). As McLaren notes, '[w]hile analogue and digital seem to be incommensurable languages, both are constitutively necessary to explain reality and to understand what forces and relations shape the human condition' (McLaren 2019: 11; see also McLaren and Jandrić 2020). Our arguments are not akin to those who destroyed mechanical looms to protest automation in the Satanic Mills of England. But rather, the arguments made here highlight the limitations inherent in those digital technologies sold to us by Silicon Valley in selfinterested attempts to chase efficiency and greater market share. In a time when information content of all stripes and colors appears online, creating an ersatz culture populated by temporary fads and fashionable apostasy, educational institutions would do well to emphasize the distinct advantages (epistemological, psychological, etc.) of in-person learning in a campus community that has its own culture, characteristics, and history. As one of us (McLaren) has written recently about his own days as a university student at the University of Toronto, and later, in Venezuela during the heyday of the Bolivarian Revolution:

Once during an undergraduate class in Middle English, held in a musty old room in Victoria College, an 1836 masterpiece of Neo-Gothic architecture complete with turrets, gargoyles, and battlements, my Chaucer professor began weeping as she read excerpts from the Canterbury Tales. Tears dropped from her cheeks onto my shoulder. I could not have felt more sublime had my father confessor sprayed me with holy water. As she walked past my desk (perhaps a seat that was warmed by Margaret Atwood's genius a decade earlier) I could 
smell the perfumed odor of ... Gothic grammar. Nothing could compare to the dining room, Ondaatje Hall, where all Junior Fellows like myself were required to wear gowns and say prayers in Latin, and sit at tables where only French or German were spoken, depending upon the day. The high table dinners were exquisite and the sherry and cigars afterwards were more so. Later I was to abandon the prurient class elitism of it all, bathed as it was in the succulent side of capitalism, but unlike the Red Guards of the same generation far away in China, I did retain a tactile appreciation for the artistic achievements of Western civilization. It was an experience to hear lectures in Convocation Hall, built in 1907 in Edwardian Baroque revival style, with a domed rotunda, or attend social events at Hart House, established in 1919 (where my mother, a clothing model, and housewife, and later a telephone switchboard operator, used to perform small roles in plays prior to WWII). (McLaren in Peters et al. 2020)

In this essay, we argue that the digitization of education must remain only a part of the university rather than supplanting it and physical spaces must retain even more reverence for the future of education. Scholars have debated the concept between digital and non-digital, especially in this outlet. ${ }^{1}$ We do not see ourselves claiming a stake in the debate that has been settled. The physical space will always have an aspect of the digital. After all, even a one-on-one meeting at a coffee shop between a doctoral student and their advisor usually has a calendar invite, two laptops, and digital currency. However, Silicon Valley does not care what we debate amongst academics, and the dynamics of the societal shifts are actually leading to cleavage of digital from physical-e.g., all online meeting spaces, no physical books library, no common areas, only working from private spaces. The argument is not that any one of these developments is bad or detrimental, rather than the cumulative expansion and the underlying totality of the ideology will lead to the downfall of higher education.

\section{The Promise of the Disruptors}

Christensen coined the 'disruption' concept of innovation in 1997 for The Innovator's Dilemma and watched his ideas spread to education. This kind of disruptor mindset can be associated with Silicon Valley and the start-up culture; sometimes described as the Californian Ideology that 'simultaneously a deeply pessimistic and repressive vision' and yet promises an 'optimistic and emancipatory form of technological determinism' (Barbrook and Cameron 1996: 14). Entrepreneurs have gone into cities set to disrupt housing and transportation with Airbnb and

\footnotetext{
1 See Special Issue of Postdigital Science and Education, The Postdigital Spaces of Higher Education, edited by James Lamb, Lucila Carvalho, Michael Gallagher, and Jeremy Knox (forthcoming in January 2022).
} 
Uber. While they seemed fun and revolutionary when first introduced, they have proven to be unstainable or detrimental to local works and housing supply. Despite their ads, these techno-bros do not care about the local community or the implications that the changes have on the social fabric of where they are implemented. What they do care about is expanding their profit and reach. It is about growth, crushing the rival and the quarterly report, or having a record-setting initial public offering (IPO).

Eyeing the changing sector, Christensen and Eyring (2011: 5) argued, '[w]ith the steady improvement of low-cost online learning technology, the prospect of competitive disruption is real. Mere budget cutting will not be enough. For the vast majority of institutions, fundamental change is essential.' Christensen et al. (2011), comparing higher education to sectors that have been disrupted like the telecommunications industry, argued for a new business model that centers on online education. Although, they did concede that the best option would be some kind of hybrid model. Others, though, have gone further. Armstrong (2001) argued these online colleges would take over the sector, while Caplan (2018) argued that, 'today's Internet teaches more effectively than old school schools for a fraction of the cost'. Universities cannot take this Silicon Valley mindset and ignore what happened in these other sectors of society. Education is a public good. Operating a public good as a profit-seeking venture.

There is a strain of essentialist thinking on education that couples with hypercapitalist ideals of markets and efficiency. In this conception, education, especially at the university level, should be piecemeal and à la carte. Craig (2015) called for universities to 'unbundle' their various offerings and services to save money, arguing only the very elite would choose a traditional residential-type college experience with the given technology of the modern world and digital capabilities available in education. They ask, why should a student pay for the athletic facilities at their institution if they never use them? Why should they cover the cost of mental health services if they will not use them? These are perfectly reasonable questions for freshman introduction educational philosophy courses to ponder, but they are coming from people in power in government and business. Those with this mindset cannot conceive that a university is a community, a social organism made up of disparate parts. Their view is of a factory model of education, producing products to be sold and monetized to the maxims.

Each new technological innovation seems to offer the opportunity to test the disruption paradigm. Jandrić and Hayes (2020) outline one such 'disruptor' in the so-called "first "blockchain university", (3) that promised "to remove the middleman from the teaching relationship' (6) and to empower students beyond passive consumers with faculty cooperation. However, the authors also wondered if these lofty promises could be kept and that the endeavor could really. Considering the Silicon Valley start-ups tend to overpromise and undersell the negatives in order to raise more money from angel investors, we remain skeptical of how blockchain (or other future promised innovations) will do any of this, fulfilling the familiar cycle that is the Californian Ideology (Barbrook and Cameron 1996). 


\section{A Future For a Few and Forgotten}

Who hears today about the Chernobyl liquidators - those civil and military personnel who dealt directly with the deadly consequences of the 1986 Chernobyl nuclear disaster in the Soviet Union by cleaning up the radioactive site of the tragedy? Similarly, who hears about the liquidators of the Fukushima Daiichi nuclear power plant who had to deal with radioactive fuel rods, containment ponds full of contaminated water, or the contaminated ruins and surrounding soil? Have these heroes been forgotten?

The Covid-19 pandemic has lionized a new hero of society: the essential worker. While many so-called knowledge sectors or 'creative classes' were able to work remotely during quarantine, the essential worker had to brave the virus because their job could not be digitized. True, unlike the heroes of Chernobyl and Fukushima who were volunteers who chose to brave an environment fraught with invisible dangers to themselves and vast at-risk populations, America's essential workers were forced (and continue to be forced as the virus mutates) to put their lives at risk to keep essential aspects of society running. People need food and daily goods to survive. Early in the pandemic, there was a panic run on toilet paper, as the public believed supplies would run out due to stoppages in logistics. However, the USA and other affluent nations did not run out of these household goods precisely because essential works kept on doing their jobs-the truck drivers, cashiers, and stockers made sure everyone could get their toilet paper. Of course, business owners could also continue to make a profit all the while. In fact, Amazon saw record profits, and billionaires like Jeff Bezos and Elon Musk only extended their bottoms like never before. But the workers risk the ignominy. These include the grocery store clerk, the delivery drivers, the factory workers, and the cleaning staff-what Marx referred to as 'productive workers'. those directly involved in producing goods or services. It is worth noting that the value added by the productive workers is significantly more than the value of the wages paid to them by their employer.

Such essential, productive workers were even dubbed 'TIME's 2020 Person of the Year Reader Poll' (Time Staff 2020). But once the pandemic became normalized, and people got used to simply Zooming to work or ordering takeout, these essential workers were cast aside and returned to their precarious jobs without any fanfare. There is rhetoric afoot that if grocery stores are forced to pay their essential workers a higher wage, then the management will simply automate their jobs away with things like self-checkout lanes. 'Brookings found that 13 of the largest retail and grocery companies in the USA earned $\$ 17.7$ billion more in the first three quarters of 2020' (Maheshwari and Corkery 2021). The pandemic has created enormous profits for the few at the expense of the many.

But the cashiers-dubbed new American heroes-are already not getting a living wage while continuing to put their lives at risk; 'labor-saving' technology joins Covid-19 as their greatest threat to survival. Even if there were no minimum wage companies would still attempt to reduce the number of employees just to save a few bucks each hour. True, automation has been replacing and will continue to replace 
jobs. The problem, however, is not the automation itself but the fact that there are no jobs in this world in which we are compelled to work in order to live and where the unemployed are condemned to die. The problem is the wage system itself which strikes underpaid women and people of color the hardest. Otherwise, automation could work to increase leisure time for workers. We are talking here about automated socialism (see Bastani 2019; Peters et al. 2019). ${ }^{2}$

There is a lesson for universities in the discarding of the essential workers once they are no longer essential. When the attention shifts, technology will replace you with something cheaper and more efficient. Increasingly, and especially since the outbreak of Covid-19, 'writing, images, audio, and video' (online) have been treated as data and manipulated and wielded 'without our knowledge and power relations are unclear' (Jandrić et al. 2021b: 761). This kind of manipulation is perfectly encapsulated in the case of Concordia University and Professor Francois-Marc Gagnon (Zamudio-Suarez 2021). A student was taking an online class with Professor Gagnon and decided to email him to let him know how much he enjoyed his lessons. Instead of finding his faculty page, he found his professor's obituary. Despite dying 2 years prior, the university had still been using Dr. Gagnon's lectures and course material. A truly morbid tale that is not all too surprising given in a higher education sector that has raced to slash costs by any means necessary. Will the universities now enshrine their curriculum in a frozen orthodoxy, dark alchemy, where learners are ensepulchered in an intellectual mausolacracy ruled by the dead?

\section{Cult of Efficiency}

For higher education, the allure of online education is reminiscent of the suburbanization of North America. Place, as in architectural space and scale, no longer matters in this view, just growth and efficiency. Welch (1998) famously refers to this unyielding devotion to measuring and counting systems for productivity as the Cult of Efficiency. The Cult forces standardizations that cut across every system, from global down to local. There is an infamous case of Western development experts visiting subsistence farmers in the Andean Mountains of Peru recorded by Goland (1993). The experts, obsessed with efficiency, noticed members of the community traveling great distances to their various plots scattered miles away. They suggested to the locals that it would be more efficient to consolidate their plots so there would be no need to travel so far for cultivation. What the experts missed was the centuries-old indigenous, cosmovisionary and local knowledge applied to doing things that minimized risk for individual families and maximized survival. Those who had consolidated their plots died, and those who had spread their plots survived. The

\footnotetext{
2 This rationale is implicit in the current uproar over the teaching of critical race theory, with conservative, White, and Trump-aligned parents claiming their children are being made uncomfortable and are sometimes traumatized by teachers claiming the USA is a country built upon systemic racism. Since parents are 'clients' and teachers 'service providers', the parents are demanding a more 'patriotic' curriculum without reference to the history of slavery or white supremacy.
} 
reason the former families survived and the latter did not was that conditions in the area were not uniform, there were droughts, flooding, and other potential disasters that could ruin a harvest. If that harvest was in one spot, then one bad season could wipe away a family. The Cult of Efficiency only recognized an unnecessary inefficiency that needed to be fixed.

Ritzer (2011: 372) characterized the logic that 'emphasizes efficiency, predictability, calculability... and control over uncertainty' inundating the world as the McDonaldization of Society. Building in the education sector, Hayes (2017: 6-8) critiqued a growing globalized standardization of higher education from neoliberal pressures with the same McDonaldization label—defined by Ritzer's logic applied to universities with visions of efficiency, predictability, calculability, and control. Indeed, institutions across the world were adopting the same structures, standards, measures, and language. Students were not in classrooms to learn, instead, they were customers who needed to be coddled and soothed, so they do not take their business elsewhere. Hayes (2017: 107) argues that this part of the McDonaldization of higher education has led to a therapeutic turn for universities, in that the 'student experience' as consumers is maximized over 'academic experience'. In this way, the curriculum or material that offends students must be excised, as the customers are always right. ${ }^{3}$

Education has been especially inculcated by these ideals through accountability measures and standardized testing (Peters 2019). These policies have been most widely adopted throughout K-12 systems, but even higher education has witnessed standardization through various kinds of accountability measures and other metrics. ${ }^{4}$ In the UK, for instance, the system of Research Excellence Framework and Teaching Excellence Framework has brought the measurement obsession to higher education in full force. Other areas around the world worship at the altar of global university rankings to decide with whom to partner or hire (Allen 2021a). McLaren (2005: 23-24) decried this kind of market-oriented higher education that emphasizes growth and 'deskills' educators. Deskilling an entire generation of professors for algorithms to auto score essays that save time, money, and humanity (Malott 2019).

\footnotetext{
${ }^{3}$ It is worthwhile remembering that, historically, wage labor was once thought to be a form of slavery and can be traced as far back as the writings of Cicero. Marx saw capitalism as a struggle between the forces of production and the social relations of production and imagined a time when knowledge becomes social and part of society's 'general intellect'. Capitalism, Marx (1973) reasoned, would not be able to survive in a world in which technological advances created conditions where workers were no longer needed to generate value production or profits. Marx sought to overcome alienation and selfestrangement through the abolition of private property and the state but his radical humanist goal was human freedom, autonomy, and well-being - the return of humans to their social essence or being, to the possibilities inherent in human sociality. How Marx would have reacted to today's technofeudalism where capitalism has merged with digital platforms (which have replaced markets) is a question that needs to be addressed.

4 See Postdigital Science and Education 3(1), which is a Special Issue on 'Measuring Excellence' in Higher Education, edited by Sarah Hayes. https://link.springer.com/journal/42438/volumes-and-issues/ 3-1. Accessed 9 November 2021.
} 
The impetus for the Cult of Efficiency forges an alliance between austerityminded neoliberals looking for budget cuts in all aspects of public life together with the Silicon Valley start-up world looking to disrupt every sector through phone apps with hopes of becoming the next billion-dollar unicorn. Malott (2019: 371) argues that the technology corporations rely on is justified by the 'old cliché that education is broken'. The promise is that their apps, algorithms, and artificial intelligence can cut costs and increase efficiency, with the same or better outcomes. The humans involved in the new innovations from the start-ups are mere customers, numbers, and dollar signs, including, educators, students, and schools.

In terms of the digitization of education backed by Silicon Valley and the like, those enamored by efficiency and growth are running a race to the bottom of lowcost online classrooms and the promise of an infinite pool of new students no longer bound by parking or dorm limitations on campus. Teaching online does not require a physical location, so no more upkeep, energy bills, or landscaping, and the entire campus can actually be sold to Google or the next great American start-up. Students do not have to waste time driving across the city to take a class-and forget the campus shuttle. When everything moves online, the university is as efficient as it can ever be. No more staff as the duties are now gone and the remaining outsourced to the Philippines. With fewer faculty, the remaining ones can simply be low-wage adjuncts, too. If there were just a way to rid the university of students, the efficiency would reach its singularity!

\section{The College 'Town'}

Higher education's gamble with digitalization is analogous to what happened in North American cities. In the mid-twentieth century, cities across the USA and Canada undertook radical 'revitalizations' through highway and beautification plans. These plans targeted so-called 'blighted' parts of towns to be demolished and replaced by pristine highways that would connect the city centers to the ever-expanding suburbs. However, as Jane Jacobs (2016) noted, the places derided as 'blight' were in many cases active and thriving communities. These urban renewal projects end up gutting community, culture, and people, often in Black areas of the cities, hollowing out the broader social connectivity of the surrounding areas (Allen 2021a, b). Once thriving societies that could support local businesses disappeared and, in their place, could be found a highway on the edge of town that led to a Big Box Store ${ }^{\mathrm{TM}}$. Mainstreet was not bombed by foreign invaders; no, instead, the destruction of communities across North American was fueled by misguided engineering practices, racial animus, and an unyielding appetite for ever-expanding growth (Marohn 2019). A halfcentury later, many of these places have never recovered from the damage inflicted by ourselves.

These urban renewal ideas have roots in the High Modern paradigms. Scott (2008) describes how these High Modernists, such as the famed architect Le Corbusier, proposed an architectural replanning of entire cities around science, technology, 
and '20th-century advances' - similar echoes are heard today by the technologists offering disruption of education through the latest social media or screen device. Zoning was key to the High Modernists, as efficiency demanded that industry be separate from living or recreation, with the goal to control the chaos of cities. In one infamous plan, Le Corbusier proposed to raze central Paris and replace it with ultramodern skyscrapers and a new business center. Today, the plan comes across as absurd and places like central Paris have become the most desirable locations on the planet. Even then, Soviet artist El Lissitzky critiqued Le Corbusier's plan as a 'city of nowhere' (Scott 2008). Indeed, hindsight allows us to see the absurdity of the 100-year-old idea blinded by the innovations of the day. Perhaps, no scholar has done more to identify different modes of production of space and recognize space as a social product or a complex social construction with political characteristics as Lefebvre (1991).

One city that was designed in the image of Le Corbusier's High Modernist sensibilities was Brasília. The capital of Brazil was planned to be segregated, regimented, and efficient. However, the humans who lived there realized that life was bland in a city that was overdesigned and controlled, even coining a phrase for the feeling as Brasilite (Scott 2008). In this environment, people could only meet others at home or work, there were too few spaces for other interactions, especially those incidental. The concept that Brasília citizens were missing has been called the 'third place' (Oldenburg and Brissett 1982). Cities designed at the human scale provide third places to meet and live, ensuring lively, flourishing environments that are lacking in the zoned-off planned segmentations that define high modern sensibilities or the American suburb. Universities, especially, provide ample third places for students, workers, and the broader community.

In many ways, universities are like miniature cities and parts of cities. They provide community and important cultural signifiers for places. In Europe, medieval towns built around their famed universities have thrived for centuries. In the USA, Land Grant Universities were founded in rural communities, and the partnership created some of the strongest and most resilient little cities in the county. Indeed, even today, China uses the university to create new places to build around. A university relocates parts of its operations to the edge of a city, a new subway stop opens, and community sprouts up around it. It is uncanny that this development pattern can be witnessed globally.

Critics may bring up the consistent 'town vs. gown' conflict that highlights elitism in higher education. These clashes often characterize the relationship between educational institutions and the surrounding communities. However, the absence of students due to Covid-19 in some communities has shown how important students can be to the local economy and culture of a place. Likewise, conflict is human. No community is without conflict, even the smallest family unit has disagreements. The university town is not a utopia. What is a perceived utopia is online education being sold by corporate interests in an educational market. They sell their vision of a seamless and efficient future. 


\section{Protecting The Educational Place}

This essay is not making the case that online education is bad or cannot be good. There is a place for online education in the future, but it should not be the place. Fawns (2019: 142) argues that "[i]deas like "digital education" are useful insofar as they encourage people to look closer at what is happening, but become problematic when used to close down ideas or attribute instrumental or essential properties to technology'. The ongoing pandemic and eventual endemic will undoubtedly bring more digitization to all facets of life. Online education brings increased access, expanded global reach, and even some alleviation of environmental impact from aspects of travel (Peters 2016; Chan et al. 2021). Digital automation in educational functions can provide outlets for critical practices, with explicit dependence on human control (Gallagher et al. 2020). In some cases, physical disabilities or injuries to teachers or students make it prohibitive to attend campus and online instruction may, in fact, be necessary. There are, however, limits to these innovations that must be taken as seriously as the perceived benefits.

Jandrić et al. (2018) and Matias and Aldern (2020) rightly argue that digital spaces in the contemporary sense are entangled with the physical world, blurring the lines between the digital and the physical. But even under such convergence, contemporary technological limitations and general unpreparedness dominated pandemic responses (Peters et al. 2021). The model of online education sold to the world has been an overreliance on screen-based curriculum, which cannot replicate the form and function of physical spaces. While online interactions are purposeful and efficient, they often miss the incidental experiences that happen on campuses or inside physical classrooms. The mingling of students, faculty, staff, and locals, the interactions between various majors - these are the university. It is not always supposed to be sterile and efficient. It is supposed to be a little messy. The freshman getting lost on the first week of the semester and the upperclassmen helping them is exactly the point. Searching Google Calendar for the Zoom meeting link from a bed just does not provide the same experience.

The Herculean efforts in training, retraining, and adapting by the educational profession for schooling in a pandemic world can only go so far. Educators report online teaching to be exhaustive (Jandrić et al. 2020, 2021a; Bista et al. 2021). The lessons provided in the experiments for the eventual endemic schooling will be invaluable. But there is only so much screen time that a person can take, and students are also craving a return to campus (Felson and Adamczyk 2021). Scroll through popular social media communities to see how a generation hates the forced enrollment to Zoom University. This is a generation dubbed 'Zoomers' who are supposedly glued to their phones! Even they recognize the importance of interacting with people in the flesh and being in a physical place (Nguyen et al. 2021). They want their chance to become lost like generations in the past; they want to find their meaning beyond the perfectly curated Zoom room or sleek Canvas page.

Universities are communities with meaning and culture that span beyond classroom lessons. Campus buildings are third places with a history that can be shared and understood by generations who have previously walked through the halls. The 
people and places around campus or university buildings are just as important to the meaning of what makes an institution an institution. The local bar down the street that has karaoke on 'university night', the mom and pop breakfast place that offers school color pancakes, the stationery shop that sells university-branded folders and pencils for just a bit more than you would like to pay are parts of a broader community.

Certainly, the physical spaces that universities occupied have long had imperfect or even painful pasts, such as the aforementioned town vs. gown conflicts or racial exclusions with which institutions have long had to grapple. In making our case for in-person learning in the physical spaces of a university campus, we remain cautious about any nostalgia seeping from our own experiences as students or as professors that may have unfairly shaped our argument, whether referring to our personal recollections (in the case of McLaren, for instance). Higher educational spaces have witnessed valiant struggles. Students have fought against recruitment by military and war-profiting company personnel on university campuses, student hunger strikes over university investments in the military-industrial complex, or debates over the Vietnam War. Women's rights, civil rights, Reserve Officers Training Corps (ROTC), abortion, gay rights, Chicano studies, or fraternity practices have defined the history of university campuses over the decades throughout North America. While many of us identify physical campus sites as sacred spaces in the struggle for civil rights and social justice, at the same time we are also aware that pandemics such as Covid-19 create conditions that will sometimes necessitate students remaining in quarantined locations at home or in other physical spaces that keep them safe from infection. In these instances, digital instruction will be necessary on a temporary basis.

Our main argument is to reject online instruction when there is no longer a serious risk of infection, in favor of the many advantages of the in-person campus experience. We are also aware of the important potential of transforming the neoliberal university campus into a counterpublic sphere so that it can operate more as a workers' commune than a business enterprise (Neary and Winn 2017). Universities do need to be more courageous in how they approach the relationship between epistemology and ethics and begin to assist the public sphere in planning for future disruptions (such as more pandemics, geopolitical struggles over water, rising food prices and wars and famines) and to study ways of both anticipating and preventing them.

The acknowledged frictions that scar the history of higher education and physical campuses can be easily swept under the rug through 'slick, user-friendly, solutions' promised by digitization (Jandrić et al. 2018). The true diversity of the institution (or lack thereof) is inescapable during a stroll through campus, seeing real faces and people, rather than the curated marketing on websites where there can now be an invented 'online Black persona' (Matias and Aldern 2020). While students may no longer have to sit in the study hall with a namesake that has a dubious legacy, they also do not get a chance to even make that discovery and bring the fight to the administration. They do not have an opportunity to occupy the president's office until their demands are met. After all, Zoom breakout rooms are just labeled Room 1 , Room 2, Room 3... and the interactions stop when the host clicks end. 
In the physical world, we cannot just escape an in-person interaction with the click of a button. On campus and within the surrounding community, we are forced to interact with a host of different kinds of people. Sometimes, universities bring Ph.D. students to live in regions where graduating from high school is considered an impressive feat. Or sometimes, polyglot international students populate a place where most of the locals are monolingual. In a time of further political polarization and divisiveness, we should be craving more of these tensions rather than smoothing out every single interaction to the perfect $4 \mathrm{~K}$ stream.

While the changing university landscape brought by the pandemic does threaten higher education, universities cannot survive by becoming YouTube. Google does YouTube better than universities ever will. But Google Maps cannot replicate what it means to be on campus on the first Monday of a new semester or the excitement in the last class right before summer begins. It is just not even comparable. We should not cede everything to the growth mindset of capitalism. The Wal-Mart Universities of the world will gladly offer online micro-credential degrees with deceased professors for pennies. Universities must recognize that the so-called 'bricks-andmortar estates' are meaningful and provide a reason to come to campus that cannot be replicated.

A university is more than classes and credentials. They are not just inputs and outputs nor simply the number of students who applied and graduated. If universities take the advice from Silicon Valley and other for-profit businesses chasing the Californian Ideology and replace their physical spaces with the shining promise of going completely digital, they will fail like our suburban experiment. Under this path, there will be a few giant corporate universities that survive and thrive. They will absorb smaller universities akin to a corporate giant buying up dying companies with the cultural cache. Then, years from now, when another student is enjoying their Zoom class and Googles the university, they will discover an obituary for a once traditional college. All that remains is a name branded for a specific region run by an umbrella organization headquartered at a PO Box in a tax haven. Everyone will have the same classes just accessed from a learning management system with different school colors. The credential will remain, but the space, the place, the people, the community, and the soul will be lost. It will be a university of nowhere.

\section{Discussion and Conclusion}

One aspect missing from Hayes' (2017) theory of McDonaldization is that McDonald's themselves often (unfortunately) offer the only local refuge for towns robbed of community through suburbanization. In his exposé of multiracial working-class communities in the USA, Ardande (2019) described how important the fast-food franchise had become to hollowed-out communities.

[I]t was important to everyone in the neighborhood. It was always packed with families and older couples, especially on the weekend mornings. In the evenings, it was filled with teenagers or young couples going out. There weren't 
really many other options. McDonald's was one of the few spaces ... open to the public that worked. (Ardande 2019: 67)

The full digitization of universities is a step beyond McDonaldization, as the erosion of physical place further robs the community that relies on the institutions. Even universities obsessed with metrics and inputs can offer third places for communities, anchors for various jobs, and reasons for being in a specific place.

Already in the short lifetime of the experiment, the turn to online education has made students and teachers feel isolated and lonely (Nguyen et al. 2021; Jandrić et al. 2020a, 2021a). Despite all educators working harder than ever before, the technology that currently exists simply cannot recreate the sense of community that is often found on campus and within a classroom. American society has already been overburdened with feelings of isolation. Researchers have even connected social isolation to the ongoing opioid epidemic sweeping parts of the USA, especially in rural places (McLean 2016). Indeed, overdose deaths did increase during the Covid-19 pandemic (Trappen and McLean 2021). For educators, this does not suggest our students will suddenly become addicts due to online classes, only that there can be high societal costs to lost community that may not be apparent for decades. In the 1950s, few forecasted that the suburban experiment would eventually connect with a massive opioid epidemic in our communities that had been hollowed out by outsourcing, Big Box stores and highway construction.

In the American suburban experiment, individualism championed over the collective, with individual car rides favored over public transport and single-family housing considered sacred castles. True public goods are afterthoughts within this mindset, especially behind gated communities. Digitization of our universities is further privatization of the once accepted public good. In a physical university, there must be classrooms, chairs, and space. In an online university, students must have their own area of study, their own material at home. While more affluent people might not even consider this a problem, what happens to those who live in cramped quarters? What happens to those with children all around the house? What happens to those without broadband Internet? All of these amenities used to be standard to a physical institution. They are pushed upon an individual in the new digital world.

The online turn for universities will only deepen these attributes, especially as space and place no longer matter because a new college that makes a student happier is just around one browser tab away. Look at the bubbles that have been created via social media. They are echo chambers and cheerleaders for the figures, media, and messages that people want to hear, not that they need to hear. These types of environments will only supercharge the concerns against academic freedom and increase in therapeutics for students seen as customers.

\section{Falling Forward}

The sector must pay attention to these calls. There is a growing distrust of universities for a variety of reasons, with a large swatch of people questioning the value of a degree, especially in the US (Parker 2019). One key reason for this bubbling distrust 
is the runaway cost to students. There are now multiple generations of students starting their adult lives with mountains of debt. The sector cannot simply continue to look at students as resources. Korn and Fuller (2021) found that many elite universities had a stable of master's degrees that left students in debt of over US\$100,000, with career prospects of earnings much lower. Universities have been sold the El Dorado Golden City, with promises that the online infrastructure that was a BandAid during Covid-19 should be taken in full future use for everyone. They will dangle growth charts and cost-saving forecasts on Excel sheets or scare tactics of falling behind the competition. For-profit university rankers have already used the pandemic to foster precarity amongst students and institutions, further selling their league tables and expertise to the sector (Shahjahan et al. 2021).

Before Covid-19, higher education was already trending toward risky growth through all-digital offerings of various programs. Even very elite universities have sold off their brand to for-profit online program managers (OPM), often of pricey online master's degree programs. 'By contrast, master's programs are a black boxthere is no requirement to publish any admissions data', reported Carey (2019). The promise of this model is that universities can dramatically expand enroll in various programs without compromising quality or standards. But these growth strategies did not always live up to their lofty promises of the for-profit OPMs, bringing with them unforeseeable costs. In some cases, for-profit OMPs have charged up to $80 \%$ of the revenue in university partner relationships (Hall and Dudley 2019).

In one of the most high-profile cases, the University of Southern California's (USC) School of Social Work outsourced some of its operations to the online provider 2U (Ryan and Hamilton 2019a). The program saw massive growth to 3500 students in 2016 up from just 900 in 2010. However, the school struggled with the bloat of new students and lower standards, revealing in 2019 that the school was losing millions in operational costs each year (Ryan and Hamilton 2019b). The partnership was a disastrous deal for the university, with USC taking in only $40 \%$ of the tuition while the for-profit company received the lion's share of $60 \%$. What is specular about this failure is that it was not a seemingly random rural school without much name recognition-USC has been one of the most well-known university brands in the USA, in the middle one the world's most dynamic cities, and has an endowment of over $\$ 5.9$ billion (Banet-Weiser 2013). If a university with the characteristics of USC cannot make this strategy, who can?

The high-profile failures do not stop with $2 \mathrm{U}$ and USC, Silicon Valley investor strategy is to throw money at so many different start-ups that one unicorn will emerge. The practice is a high-functioning lottery. For instance, rather than partnering in the case of $2 \mathrm{U}$, the Lambda School promised to compete with universities directly through boot camps, the classic disputer to the space. But the company has been mired in controversy after being sued for a false advertisement that revealed only $30 \%$ of its graduates could be placed into jobs (Woo 2021) and eventually reshuffled its operations (Mascarenhas 2021). The failure of this kind, though, does not matter in the Californian Ideology when every venture is a lottery ticket (Barbrook and Cameron 1996) —Lambda can merely be tossed away after finding out it is not a winner. The difference is that education cannot play roulette 
with the future of students' educational lives. Institutions of education must be institutions to build common trust in the system that helped it thrive for so long.

\section{Lessons Learned and New Visions}

Universities cannot discount everything that happened during Covid-19, as there will be trends that are never going away. For instance, some meetings are perfectly fine to conduct via Zoom. But if professors find that their in-person classes can always be $100 \%$ replicated online, it might be time to update the curriculum with some innovative pedagogy that takes consideration of space and place. Likewise, if the campus has no meaning or connection to the surrounding community it is located in, then it is time for the administration to reach and foster deeper connections. Local connections create stronger bonds, especially important in an environment of growing institutional distrust. For instance, Americans have consistently held negative perceptions of the national education system while at the same time rating their local schools more positively-patterns that were consistent throughout the pandemic (Starr 2021).

There is something undeniably human about the local or the familiar, along with the people and institutions that inhabit this uniquely personal space for everyone. Martin Luther King famously said, ' $[t]$ here is nothing more powerful than the tramp, tramp of marching feet'. While today he has a near-universal approval rating, he was loathed by large portions of the country, even targeted by the FBI as a supposed threat to national security. King was a self-proclaimed gadfly-he was there in-person protesting and causing a scene to bring attention to the cause of social justice. His legacy has lived on, especially for the younger generations, with a robust protest movement over various eras. Most recently, this display could be seen with the George Floyd protests in the summer of 2021. Anyone could watch these happening live throughout the summer on live streaming channels such as Woke.net. These incredible images of people around the world marching, protesting, and drawing attention to the cause were undoubtedly amplified due to social media. We could see them happening live, but they grabbed our attention like no other recent movement because we were seeing that people were there in-person on the streets, sometimes our own streets. It was not simply a tweet or a hashtag; those are just organizing tools.

The lesson should not be to simply discount all online education or communities. In fact, in the report that most Zoomers preferred in-person classes (Nguyen et al. 2021), there was still a small minority of students who wanted online education. Georgia Institute of Technology, for instance, has created an online computer science degree that is a fraction of the cost of competitors that has been well-received by the sector (Carey 2019). There is space for these students and environments. After all, there are certainly communities created with ties through massively multiplayer online (MMO) games such as guilds on World of Warcraft. These ties and relationships can be real, even if constructed virtually. Likewise, people with disabilities or other concerns that disallows them from returning to campus may request accommodations that offer them a digital space within a university. These must be parts of an 
institution going forward and they cannot be forgotten under the same profit motive that drives Silicon Valley. The good news is that the infrastructure already exists to continue making these accommodations to those who absolutely need them; the bad news is that some of this infrastructure has already been hijacked by corporate interests. The threat is perfectly exhibited by Facebook becoming 'Meta' and heavily investing in the virtual reality Metaverse (Young 2021). Zuckerberg and his company are already targeting physical education spaces. The question everyone should be asking: do we really want our universities to look more like Facebook?

There are new visions for organizing the university along socialist trajectories that we find valuable, although they are not without difficult challenges. We find the ideas of Josh Winn (2015) and Mike Neary (2020) particularly instructive. The composition of capitalism has gone through many transformations since Marx's time (Keynesian capitalism, neoliberal capitalism, communicative, or cognitive capitalism), but Marx's labor theory of value still offers much explanatory power today, as we acknowledge that major economic crashes have powerful impacts on families and local and international communities and the educational institutions that serve them. The crises haunting neoliberal capitalism are very real. This new century has already witnessed three economic crashes $(2000$, 2008, and 2020), each worse than the one before, underlining the core salient issues facing the US population such as the extreme levels of debt in the USAgovernment, corporate, and household—which are all at historical records and rising. Extreme inequality has become a central distinguishing feature of life in the USA, and the Covid-19 pandemic has highlighted and exacerbated this economic inequality, often along racial lines, as rising poverty and social divisions escalate (Wolff 2021).

The world was shocked at how a rich global superpower like the USA (that has $4.25 \%$ of the world's population yet accounts for about $20 \%$ of global deaths from Covid-19) could have failed so miserably to cope with a viral pandemic (Wolff 2021). As neoliberal capitalism degenerates further into a neo-feudal-austeritygangster-capitalism with its megabanks and megafirms, critical educators look to education to bring about opportunities to create a social universe in which value production (i.e., monetized wealth) no longer becomes the basis of everyday life, including university life. They look, in other words, toward prosperity through cooperation rather than competition. Clearly, the neoliberal university has to move beyond neoliberalism and that means participating in new social relations of production and innovative cultural and institutional relations.

Winn (2015) and Neary (2020) have contributed to a reimagining of the university outside of the constraints of neoliberal capital's cult of efficiency, business-driven objectives and instrumentalism that is designed to support the future development of corporations. They have contributed to developing the framework of a worker-cooperative university with teachers and students functioning as producers for the public good, as protagonistic agents furthering the development of new production relations for the commons, for the public good. The purpose of the university as a worker cooperative is to bring teachers and students together 
so that they can become collective agents of historical development. It requires theorizing the role of labor and property in a university context (Winn 2015).

Here, university campuses can break out of the role and form of the factory and become places of solidarity with social movements, new and old, as well as labor unions and teachers unions who may be open to socialist alternatives. Given that 'cooperative values and principles are already aligned with what we might think of as academic values and principles', it becomes increasingly possible to advance new initiatives for reimaging universities on the model of the worker-cooperative rather than corporate-owned factory and in the context of the student as producer (Winn 2015: 41). The cooperative values that could inform the new design of the university would include, according to Winn: Self-help, Self-responsibility, Democracy, Equality, Equity, and Solidarity. The principles are Voluntary and Open Membership; Democratic Member Control; Member Economic Participation; Autonomy and Independence; Education, Training and Information; Cooperation among Cooperatives; and Concern for Community. Key characteristics of worker cooperatives:

are concerned with the dignity of work and the importance of democratic selfmanagement; the free association of workers; that members of the co-operative collectively employ themselves to undertake the work; the distinction of worker co-operatives from wage-labor and individual self-employment; democratic decision-making; and autonomy from the State and other third-parties with respect to management of the co-operative and control over the means of production. (Winn 2015: 42)

The platform for building worker cooperatives and for rethinking the very idea of academic labor in this era of cognitive capitalism would, in this model, be the international cooperative movement (Winn 2015).

Winn's (2015) and Neary's (2020) call for the transformation of the university into a worker-owned and managed cooperative university that would control the means of knowledge production. A model that could potentially produce new forms of social knowledge through a 'common ownership' form of property relations that transforms the distinction between 'public' and 'private' in order to create an 'aacademic commons' designed for the good of the community. This would involve a new type of student-teacher relationship through forms of solidarity, equality, and mutuality in terms of the division of labor. Here, neoliberal business models based on institutional precedents are replaced by Freirean dialogical models grounded in historical materialist analysis that stresses the development of critical consciousness and protagonistic agency and what Winn (2015) and Neary (2020) refer to as the student as producer. Covid-19, however, forced an entire generation to shift their lives online, moving further away from these types of community approaches and only entrenching the Silicon Valley model to higher education. The lesson of the pandemic should be that the promises of growth, efficiency, and commercial digitization from for-profit businesses should not replace the local commitment, physical space, and public good of universities. If the latter ideals are abandoned for the former, it will be the downfall of our sector. 


\section{References}

Allen, R. M. (2021a). Commensuration of the globalised higher education sector: how university rankings act as a credential for world-class status in China. Compare: A Journal of Comparative and International Education, 51(6), 920-938. https://doi.org/10.1080/03057925.2019.1686607.

Allen, R. M. (2021b). The road to ruin - how the car drove US cities to the brink. Financial Times, 5 November. https://www.ft.com/content/27169841-7ee3-481e-919d-41b247e401f6. Accessed 9 November 2021.

Armstrong, L. (2001). A new game in town: Competitive higher education. Information, Communication \& Society, 4(4), 479-506. https://doi.org/10.1080/13691180110096987.

Arnade, C. (2019). Dignity: Seeking respect in back row America. New York: Sentinel.

Baines, P. (2021). Universities must swap physical for digital estates - at warp speed. Times Higher Education, 29 January. https://www.timeshighereducation.com/opinion/universities-must-swap-physicaldigital-estates-warp-speed. Accessed 9 November 2021.

Banet-Weiser, S. (2013). Rate your knowledge: The branded university. In M. P. McAllister \& E. West (Eds.), The Routledge companion to advertising and promotional culture (pp. 306-320). New York: Routledge.

Barbrook, R., \& Cameron, A. (1996). The californian ideology. Science as Culture, 6(1), 44-72. https:// doi.org/10.1080/09505439609526455.

Bastani, A. (2019). Fully Automated Luxury Communism: A Manifesto. London: Verso.

Bista, K., Allen, R. M., \& Chan, R. Y. (Eds.). (2021). Impacts of COVID-19 on International Students and the Future of Student Mobility: International Perspectives and Experiences. New York: Routledge.

Caplan, B. (2018). The case against education: why the education system is a waste of time and money. Princeton, NJ: Princeton University Press.

Carey, K. (2019). The creeping capitalist takeover of higher education. The Huffington Post, 1 April. https://www.huffpost.com/highline/article/capitalist-takeover-college/. Accessed 9 November 2021.

Chan, R. Y., Bista, K., \& Allen, R. M. (Eds.). (2021). Online teaching and learning in higher education during COVID-19: International perspectives and experiences. New York: Routledge.

Christensen, C. M. (1997). The Innovator's Dilemma: When New Technologies Cause Great Firms to Fail. Boston, MA: Harvard Business School Press.

Christensen, C. M., Horn, M. B., Caldera, L., \& Soares, L. (2011). Disrupting College: How Disruptive Innovation Can Deliver Quality and Affordability to Postsecondary Education. Washington, DC: Center for American Progress and Innosight Institute. https://cdn.americanprogress.org/wpcontent/uploads/issues/2011/02/pdf/disrupting_college.pdf?_ga=2.204354704.1012516018. 1636450184-783600451.1636450184. Accessed 9 November 2021.

Christensen, C., \& Eyring, H. (2011). The innovative university: changing the DNA of higher education from the inside out. San Francisco, CA: Jossey-Bass.

Craig, R. (2015). College disrupted: The great unbundling of higher education. New York: St. Martin's Press.

Doyle, W. R. (2009). Online education: The revolution that wasn't. Change, 41(3), 56-58. https://doi.org/ 10.3200/CHNG.41.3.56-58.

Fawns, T. (2019). Postdigital education in design and practice. Postdigital Science and Education, 1(1), 132-145. https://doi.org/10.1007/s42438-018-0021-8.

Felson, J., \& Adamczyk, A. (2021). Online or in Person? ExaminingCollege Decisions to Reopen during the COVID-19 Pandemic in Fall 2020. Socius, 7. https://doi.org/10.1177/2378023120988203.

Gallagher, M., Breines, M., \& Blaney, M. (2020). Ontological Transparency, (In)visibility, and Hidden Curricula: Critical Pedagogy Amidst Contentious Edtech. Postdigital Science and Education, 2(3), 425-443. https://doi.org/10.1007/s42438-020-00198-1.

Goland, C. (1993). Field scattering as agricultural risk management: A case study from Cuyo Cuyo, Department of Puno, Peru. Mountain Research and Development, 13(4), 317-338. https://doi.org/ $10.2307 / 3673760$.

Hall, S., \& Dudley, T. (2019). Dear colleges: Take control of your online courses. New York and Washington: The Century Foundation. 12 September. https://tcf.org/content/report/dear-colleges-take-controlonline-courses/. Accessed 9 November 2021.

Hayes, D. (2017). Beyond McDonaldization: visions of higher education. Abingdon, Oxon, New York: Routledge. 
Hodges, C., Moore, S., Lockee, B., Trust, T., \& Bond, A. (2020). The difference between emergency remote teaching and online learning. Educause Review, 27 March. https://er.educause.edu/articles/2020/3/thedifference-between-emergency-remote-teaching-and-online-learning. Accessed 23 November 2021.

Jacobs, J. (2016). The death and life of great American cities. New York: Vintage.

Jandrić, P., \& Hayes, S. (2020). The Blockchain University: Disrupting 'disruption'. In M. De Laat, T. Ryberg, N. B. Dohn, S. B. Hansen, \& J. J. Hansen (Eds.), Proceedings for the Twelfth International Conference on Networked Learning (pp. 207-213). Aalborg: University of Aalborg. https://www. networkedlearning.aau.dk/digitalAssets/853/853931_proceedings_nlc2020_20.09.07.pdf. Accessed 9 November 2021

Jandrić, P., \& McLaren, P. (2020). Critical intellectuals in postdigital times. Policy Futures in Education, 19(6), 626-639. https://doi.org/10.1177/1478210320964372.

Jandrić,P., Bozkurt, A., McKee, M., Hayes, S. (2021b). Teaching in the Age of Covid-19- A Longitudinal Study. Postdigital Science and Education, 3(3),743-770. https://doi.org/10.1007/s42438021-00252-6.

Jandrić, P., Hayes, D., Truelove, I., Levinson, P., Mayo, P., Ryberg, T., Monzó, L.D., Allen, Q., Stewart, P.A., Carr, P.R., Jackson, L., Bridges, S., Escaño, C., Grauslund, D., Mañero, J., Lukoko, H.O., Bryant, P., Fuentes Martinez, A., Gibbons, A., Sturm, S., Rose, J., Chuma, M.M., Biličić, E., Pfohl, S., Gustafsson, U., Arantes, J.A., Ford, D.R., Kihwele, J.E., Mozelius, P., Suoranta, J., Jurjević, L., Jurčević, M., Steketee, A., Irwin, J., White, E.J., Davidsen, J., Jaldemark, J., Abegglen, S., Burns, T., Sinfield, S., Kirylo, J.D., Batarelo Kokić, I., Stewart, G.T., Rikowski, G., Lisberg Christensen, L., Arndt, S., Pyyhtinen, O., Reitz, C., Lodahl, M., Humble, N., Buchanan, R., Forster, D.J., Kishore, P., Ozoliņ̌s, J., Sharma, N., Urvashi, S., Nejad, H.G., Hood, N., Tesar, M., Wang, Y., Wright, J., Brown, J.B., Prinsloo, P., Kaur, K., Mukherjee, M., Novak, R., Shukla, R., Hollings, S., Konnerup, U., Mallya, M., Olorundare, A., Achieng-Evensen, C., Philip, A.P., Hazzan, M.K., Stockbridge, K., Komolafe, B.F., Bolanle, O.F., Hogan, M., Redder, B., Sattarzadeh, S.D., Jopling, M., SooHoo, S., Devine, N., \& Hayes, S. (2020). Teaching in The Age of Covid-19. Postdigital Science and Education, 2(3), 1069-1230. https://doi.org/10.1007/s42438-020-00169-6.

Jandrić, P., Knox, J., Besley, T., Ryberg, T., Suoranta, J., \& Hayes, S. (2018). Postdigital Science and Education. Educational Philosophy and Theory, 50(10), 893-899. https://doi.org/10.1080/00131857. 2018.1454000.

Jandrić,P., Hayes, D., Levinson, P., Lisberg Christensen, L., Lukoko, H.O., Kihwele, J. E., Brown, J. B., Reitz, C., Mozelius, P., Nejad, H. G.,Fuentes Martinez, A., Arantes, J. A., Jackson, L., Gustafsson, U., Abegglen,S., Burns, T., Sinfield, S., Hogan, M., Kishore, P., Carr, P. R., BatareloKokić, I., Prinsloo, P., Grauslund, D., Steketee, A., Achieng-Evensen, C.,Komolafe, B. F., Suoranta, J., Hood, N., Tesar, M., Rose, J., Humble, N.,Kirylo, J. D., Mañero, J., Monzó, L. D., Lodahl, M., Jaldemark, J., Bridges, S.M., Sharma, N., Davidsen, J., Ozoliņ̌̌, J., Bryant, P., Escaño, C., Irwin, J.,Kaur, K., Pfohl, S., Stockbridge, K., Ryberg, T., Pyyhtinen, O., SooHoo, S.,Hazzan, M. K., Wright, J., Hollings, S., Arndt, S., Gibbons, A., Urvashi, S.,Forster, D. J., Truelove, I., Mayo, P., Rikowski, G., Stewart, P. A., Jopling,M., Stewart, G. T., Buchanan, R., Devine, N., Shukla, R., Novak, R., Mallya,M., Biličić, E., Sturm, S., Sattarzadeh, S. D., Philip, A. P., Redder, B.,White, E. J., Ford, D. R., Allen, Q., Mukherjee, M., \& Hayes, S. (2021a).Teaching in the Age of Covid-19-1 Year Later. Postdigital Science andEducation, 3(3), 1073-1223. https://doi.org/10. 1007/s42438-021-00243-7.

Korn, M., \& Fuller, A. (2021). 'Financially Hobbled for Life': The Elite Master's Degrees That Don't Pay Off. The Wall Street Journal, 8 July. https://www.wsj.com/articles/financially-hobbled-for-life-theelite-masters-degrees-that-dont-pay-off-11625752773. Accessed 9 November 2021.

Lefebvre, H., Smith, D., \& Harvey, D. (1991). The production of space. Oxford, UK: Blackwell Publishing.

Maheshwari, S., \& Corkery, M. (2021). 'We Are Forgotten': Grocery Workers Hope for Higher Pay and Vaccinations. The New York Times, 8 February. https://www.nytimes.com/2021/02/08/business/ grocery-workers-hero-pay-vaccines.html. Accessed 9 November 2021.

Malott, C. (2019). The sublation of digital education. Postdigital Science and Education, 2(2), 365379. https://doi.org/10.1007/s42438-019-00083-6.

Marohn Jr, C. L. (2019). Strong towns: A bottom-up revolution to rebuild American prosperity. Hoboken, NJ: John Wiley \& Sons.

Marx, K. (1973). The Grundrisse. https://www.marxists.org/archive/marx/works/1857/grundrisse/. Accessed 9 November 2021. 
Mascarenhas, N. (2021). Lambda School Lays off 65 Employees amid Restructuring. TechCrunch, 30 April. https://techcrunch.com/2021/04/29/lambda-school-lays-off-65-employees-amid-restructuring/. Accessed 9 November 2021.

Matias, C. E., \& Aldern, J. (2020). (Un) Common White Sense: the Whiteness Behind Digital Media. Postdigital Science and Education, 2(2), 330-347. https://doi.org/10.1007/ s42438-019-00076-5.

McLaren, P. (2005). Capitalists and conquerors: A critical pedagogy against empire. Lanham, MA: Rowman \& Littlefield Publishers.

McLaren, P. (2019). Reclaiming the Present or a Return to the Ash Heap of the Future?. Postdigital Science and Education, 1(1), 10-13. https://doi.org/10.1007/s42438-018-0015-6.

McLaren, P., \& Jandrić, P. (2020). Postdigital dialogues on critical pedagogy, liberation theology and information technology. London: Bloomsbury.

McLean, K. (2016). "There's nothing here": Deindustrialization as risk environment for overdose. International Journal of Drug Policy, 29, 19-26. https://doi.org/10.1016/j.drugpo.2016.01.009.

Neary, M. (2020). Student as producer: How do revolutionary teachers teach?. Winchester: John Hunt Publishing.

Neary, M., \& Winn, J. (2017). There is an alternative: A report on an action research project to develop a framework for co-operative higher education. Learning and Teaching, 10(1), 87-105.

Nguyen, T., Netto, C. L., Wilkins, J. F., Bröker, P., Vargas, E. E., Sealfon, C. D., ... \& Stein, G. M. (2021). Insights into students' experiences and perceptions of remote learning methods: from the COVID-19 pandemic to best practice for the future. Frontiers in Education, 6, 647986. https://doi.org/10.3389/feduc. 2021.647986.

Oldenburg, R., \& Brissett, D. (1982). The third place. Qualitative sociology, 5(4), 265-284. https://doi. org/10.1007/BF00986754.

Parker, K. (2019). The growing partisan divide in views of higher education. Pew Research Center, 19 August. https://www.pewresearch.org/social-trends/2019/08/19/the-growing-partisan-divide-in-viewsof-higher-education-2/. Accessed 9 November 2021.

Peters, M. A. (2019). Global university rankings: Metrics, performance, governance. Educational, Philosophy and Theory, 51(1), 5-13. https://doi.org/10.1080/00131857.2017.1381472.

Peters, M. A. (2016). Inside the global teaching machine: MOOCs, academic labour and the future of the university. Learning and Teaching, 9(2), 66-88. https://doi.org/10.3167/latiss.2016.090204.

Peters, M. A., Jandrić, P., \& Hayes, S. (2021). Biodigital philosophy, technological convergence, and postdigital knowledge ecologies. Postdigital Science and Education, 3(2), 370-388. https://doi.org/ 10.1007/s42438-020-00211-7.

Peters,M. A., Rizvi, F., McCulloch, G., Gibbs, P., Gorur, R., Hong, M., ... \&Misiaszek, L. (2020). Reimagining the new pedagogical possibilities foruniversities post-Covid-19: An EPAT Collective Project. Educational Philosophy and Theory. https://doi.org/10.1080/00131857.2020.1777655.

Peters, M. A., Jandrić, P., \& Means, A. J. (Eds.). (2019). Education and Technological Unemployment. Singapore: Springer.

Ralston, S. J. (2021). Higher Education's microcredentialing craze: a postdigital-Deweyan critique. Postdigital Science and Education, 3(1), 83-101. https://doi.org/10.1007/s42438-020-00121-8.

Ritzer, G. (2011). The McDonaldization of society. Pine Forge Press.

Ryan, H., \& Hamilton, M. (2019a). Online degrees made USC the world's biggest social work school. Then things went terribly wrong. Los Angeles Times, 6 June. https://www.latimes.com/local/laffnow/la-meusc-social-work-20190606-story.html. Accessed 9 November 2021.

Ryan, H., \& Hamilton, M. (2019b). USC considers deep cuts at social work school after revelations of gaping deficit. Los Angeles Times, 8 May. https://www.latimes.com/local/lanow/la-me-ln-uscsocial-work-finances-20190508-story.html. Accessed 9 November 2021.

Scott, J. C. (2008). Seeing like a state. London: Yale University Press.

Shahjahan, R. A., Grimm, A., \& Allen, R. M. (2021). The "LOOMING DISASTER" for higher education: how commercial rankers use social media to amplify and foster affect. Higher Education. https://doi.org/10.1007/s10734-021-00762-z.

Starr, J. P. (2021). The pandemic and the PDK Poll. Phi Delta Kappan Phi. Delta Kappa International. https://pdkpoll.org/wp-content/uploads/2021/09/Poll53_final.pdf. Accessed 9 November 2021.

Time Staff. (2020). Essential Workers Win TIME's 2020 Person of the Year Reader Poll. Time, 7 December. https://time.com/5917600/person-of-the-year-reader-poll-results-2020/. Accessed 9 November 2021. 
Trappen, S. L., \& McLean, K. J. (2021). Policing pain: A qualitative study of non-criminal justice approaches to managing opioid overdose during the COVID-19 pandemic. Journal of Prevention \& Intervention in the Community, 49(2), 136-151. https://doi.org/10.1080/10852352.2021.1908206.

Welch, A. R. (1998). The cult of efficiency in education: Comparative reflections on the reality and the rhetoric. Comparative education, 34(2), 157-175. https://doi.org/10.1080/03050069828252.

Winn, J. (2015). The co-operative university: Labour, property and pedagogy. Power and Education, 7(1), 39-55. 10.1177\%2F1757743814567386.

Wolff, R, D. (2021). Why the Troubled U.S. Empire Could Quickly Fall Apart. Counterpunch, 1 November. https://www.counterpunch.org/2021/11/01/why-the-troubled-u-s-empire-could-quickly-fallapart/. Accessed 9 November 2021.

Woo, V. (2021) Lambda School Promised a Fast and Cheap Path to a Lucrative Tech Career. Leaked Documents and Former Students Cast Doubt on That Claim. Business Insider, 25 October. https://www.businessinsider.com/lambda-school-promised-lucrative-tech-coding-career-low-jobplacement-2021-10. Accessed 9 November 2021.

Young, J. R. (2021). As Facebook Changes Name to Meta, Company Wants to Pull Education Into Its 'Metaverse'. EdSurge: International Society for Technology in Education. https:/www.edsurge.com/ news/2021-10-29-as-facebook-changes-name-to-meta-education-is-part-of-new-vision. Accessed 9 November 2021.

Zamudio-Suarez, F. (2021). The dead professor and the surprised student. The Chronicle of Higher Education, 30 January. https://www.chronicle.com/newsletter/weekly-briefing/2021-01-30. Accessed 9 November 2021. 